\title{
Purification and Properties of Endopolygalacturonase from Ganoderma lucidum
}

\author{
By H. LALITHA KUMARI AND M. SIRSI \\ Microbiology and Pharmacology Laboratory, Indian Institute of Science, \\ Bangalore 12, India
}

(Accepted for publication I January I97I)

SUMMARY

The enzyme endopolygalacturonase secreted by the fungus Ganoderma lucidum was purified by a three-step procedure until pectin methylesterase was no longer detectable. The endopolygalacturonase activity was inhibited by divalent metal ions. The enzyme had a peak of activity at $\mathrm{pH} 5.4$ and two temperature optima: one at $50^{\circ}$ and the other at $70^{\circ}$.

\section{NTRODUCTION}

The arecanut palms in Mysore State (India) are subject to a disease, 'Anabe roga', or foot rot, caused by the fungus Ganoderma lucidum. Although the pathogenicity of the fungus has been recorded (Watt, I90I; Venkatarayan, I936; Naidu, Kumar \& Sannamarappa, I966), little is known about the physiological and biochemical aspects of this disease.

In many plant diseases the extracellular enzymes and, in particular, pectolytic enzymes secreted by the pathogens are known to play an important role in pathogenesis (Wood, 1959, I960; Brown, 1955, 1965; Sadasivan \& Subramanian, 1963; Bateman \& Millar, 1966). Such an enzyme may be active in the formation of rot induced by Ganoderma lucidum. The purification and properties of the enzyme endopolygalacturonase (EC 3.2.1.15) are reported in this paper.

\section{METHODS}

Chemicals. These were obtained as follows: pectin and polygalacturonic acid from Eastman Kodak Company, galacturonic acid from British Drug Houses and the fungicides maneb, zineb, and Blitox-50 as gifts from Tata Fison Industries Ltd, Bangalore. Other chemicals used were of Analar and reagent grade.

Culture. The culture of Ganoderma lucidum was obtained from the Indian Agricultural Research Institute, Delhi, India, and was maintained on potato-dextrose agar (PDA) slants at room temperature. For the preparation of inoculum, a uniform suspension of a 5 to 6 day culture grown on a PDA slant was made. To the culture $5 \mathrm{ml}$. of sterile distilled water was added. With the inoculating loop, the soft growth on the slant was scraped gently and broken down to small pieces by rubbing against the sides of the test tube. The culture in suspension was transferred to another sterile test tube and shaken with glass beads. From this $0 . \mathrm{I} \mathrm{ml}$. was added to $250 \mathrm{ml}$. (in a I 1. Roux flask) of medium which comprised $(\%, \mathrm{w} / \mathrm{v})$ : pectin, $\mathrm{I} \cdot \mathrm{O} \%$; ammonium 
tartrate, $\mathrm{I} \cdot 0 \% ; \mathrm{KH}_{2} \mathrm{PO}_{4}, 0 . \mathrm{I} \%$; and $\mathrm{MgSO}_{4} \cdot 7 \mathrm{H}_{2} \mathrm{O}, 0.05 \%$; initial $\mathrm{pH}$ of the medium, $5^{\circ} 0$ to $5^{\cdot 2}$. The culture was incubated at room temperature $\left(22^{\circ}\right.$ to $\left.27^{\circ}\right)$.

Assay method. One unit (u) of polygalacturonase (PG) was the amount of enzyme at $\mathrm{pH} 5.4$ and $30^{\circ}$ that released I $\mu$ mole of reducing group $/ \mathrm{min}$. from polygalacturonic acid. The substrate concentration was $0.5 \%(\mathrm{w} / \mathrm{v})$ in 0.1 M-sodium acetate buffer. The increase in aldehyde groups was measured in $5 \mathrm{ml}$. samples of the reaction mixture by hypoiodite oxidation (Jansen \& MacDonnell, 1945).

The pectin methylesterase (PME) activity was followed by titrating at appropriate intervals the liberated carboxyl groups with $0.02 \mathrm{~N}-\mathrm{NaOH}$ (Bilimoria, I96I, I962). The unit of pectin methyl esterase is the amount of enzyme that releases I mole of carboxyl groups/min. at $\mathrm{pH} 6.8$ from pectin solution at $30^{\circ}$.

The assays for pectin trans-eliminases were based on the enzymic production of materials that have an extinction maximum at $235 \mathrm{~nm}$. (Edstrom \& Phaff, 1964). Pectin and polygalacturonic acids were used as substrates.

Protein concentrations were determined by the method of Warburg \& Christian (I94I).

Paper chromatography. Unidimensional descending paper chromatography on Whatman no. I filter paper was carried out with butan-I-ol + acetic acid + water $(4: 3: 3)$ as solvent system. Fifty to I00 $\mu \mathrm{l}$. of the reaction mixture was applied to the filter paper. The strips were developed at room temperature for $18 \mathrm{~h}$. Dried papers were sprayed with a solution of $0.1 \%(\mathrm{w} / \mathrm{v})$ bromophenol blue in $95 \%$ aqueous ethanol (pH 6.5). The galacturonic acid was identified by comparison with an authentic sample. The di-, tri- and tetragalacturonides were identified by calculation of $R_{m}$ value and plotting a graph, as shown by Hathway \& Seakins (1958), where

$$
R_{m}=\log \left(\mathrm{I} / R_{F}-\mathrm{I}\right) \text {. }
$$

\section{RESULTS}

An initial test of the culture fluid and a cell-free extract of the mycelium showed the presence of polygalacturonase and pectin methylesterase activities. However, the PG and PME activities were higher in the culture fluid (PGu 0.02 and PEu $0.01 / \mathrm{ml}$, of the reaction mixture) than in the cell-free extract of the mycelium (PGu 0.008/ml. of the reaction mixture and negligible PME). No trans-eliminase activity was detected at $\mathrm{pH}$ values from 4.5 to 8.0 with pectin or polygalacturonic acid as substrates.

Course of enzyme secretion. The secretion of polygalacturonase was followed as a function of time. When the fungus had formed a surface deck, samples were harvested periodically and the activity estimated in the culture fluid. The results are presented in Fig. I. PME was demonstrated qualitatively to be present from the tenth day onwards. Since maximum PG activity was observed between 18 and 20 days, further work was done with 20 day cultures.

Purification of polygalacturonase. Because PME would have interfered with the study of the properties of polygalacturonase, purification of the culture fluid was directed towards removal of this activity. The culture fluid was dialysed against distilled water for $\mathrm{I} 2 \mathrm{~h}$. at $\mathrm{o}^{\circ}$, and then treated with 3 vol. of cold acetone. The precipitate formed was collected by centrifugation at $10,000 \mathrm{~g}$ for $\mathrm{I} 5 \mathrm{~min}$. in a Lourdes refrigerated centrifuge, dissolved in water and centrifuged again to remove insoluble material.

Subsequently, $\left(\mathrm{NH}_{4}\right)_{2} \mathrm{SO}$ fractionation was done. The supernatant obtained after 
$70 \%$ saturation (which contained most of the enzyme activity) was dialysed and used for further purification.

Alumina $\mathrm{C} \gamma$ gel ( $6 \mathrm{mg}$./ $/ \mathrm{roml}$ ) was added ( $20 \%$ by vol.) to the enzyme solution obtained from the previous step. The mixture was stirred for $15 \mathrm{~min}$. in the cold and

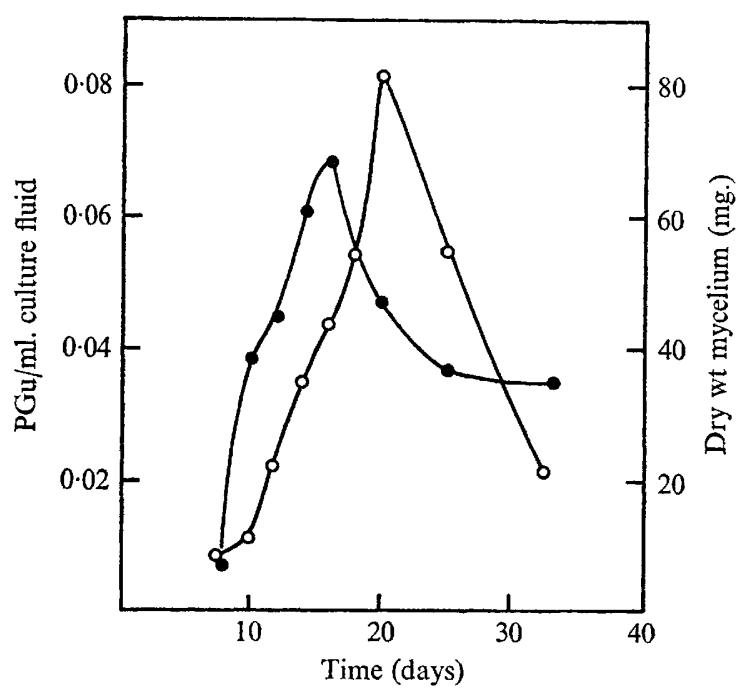

Fig. I. Secretion of polygalacturonase as a function of time. The substrate was $0.5 \%$ polygalacturonic acid in $0 . \mathrm{I} \mathrm{M}-\mathrm{Na}$ acetate buffer, $\mathrm{pH} 5.4 ; 2.5 \mathrm{ml}$. culture fluid was used/10 ml. reaction mixture (room temperature). 9 , Dry wt mycelium; $\bigcirc$, enzyme activity.

Table I. Purification of polygalacturonase

\section{Purification step}

Crude culture fluid Acetone precipitation Ammonium sulphate (70\%) (supernatant)

Alumina $\mathbf{C} \gamma$ gel adsorption and elution

$\begin{array}{cc}\begin{array}{c}\text { Specific activity } \\ \text { (PGu/mg. protein) }\end{array} & \begin{array}{c}\text { Recovery } \\ (\%)\end{array} \\ 0.2 & 100 \\ 1 \cdot 3 & 128.7 \\ 4.6 & 101.8 \\ 12.9 & 49 \cdot 2\end{array}$

Specific activity (PEu/mg. protein)

0.19

0.40

Trace

Nil

centrifuged. The supernatant liquid was inactive and was discarded. The gel was dispersed in a small volume of $0 \cdot 1$ M-potassium phosphate buffer, $\mathrm{pH} 7 \cdot 0$, and centrifuged after $15 \mathrm{~min}$. Only $49 \%$ of the activity was recovered in the supernatant, but specific activity was substantially increased (Table I).

Use of calcium phosphate gel and isoelectric precipitation did not result in an increase in specific activity.

Substrate specificity. The rate of hydrolysis of pectin and polygalacturonic acid was measured. The polygalacturonic acid was hydrolysed fairly rapidly but pectin was almost resistant to attack (Fig. 2). Prolonged digestion (72 h.) of polygalacturonic acid resulted in $68.7 \%$ hydrolysis.

The hydrolysis of the substrate was followed chromatographically. At an early stage polygalacturonic acid was broken down into higher uronides $\left(R_{F} 0.039,0.08\right.$ 
and $0 . I_{5}$ ), which later disappeared with the appearance of mono- and digalacturonides $\left(R_{F} 0.43\right.$ and 0.25 respectively).

Effect of $\mathrm{pH}$ on the rate of hydrolysis. The optimum $\mathrm{pH}$ for activity of the partially purified enzyme was 5.5 in sodium acetate-acetic acid buffer (Fig. 3).

Effect of temperature on enzyme activity. The enzyme had two temperature optima: one at $50^{\circ}$ and the other at $70^{\circ}$. The enzyme was inactivated at temperatures above $70^{\circ}$ (Fig. 4). It was thought that the peak at $70^{\circ}$ might be due to the presence of an

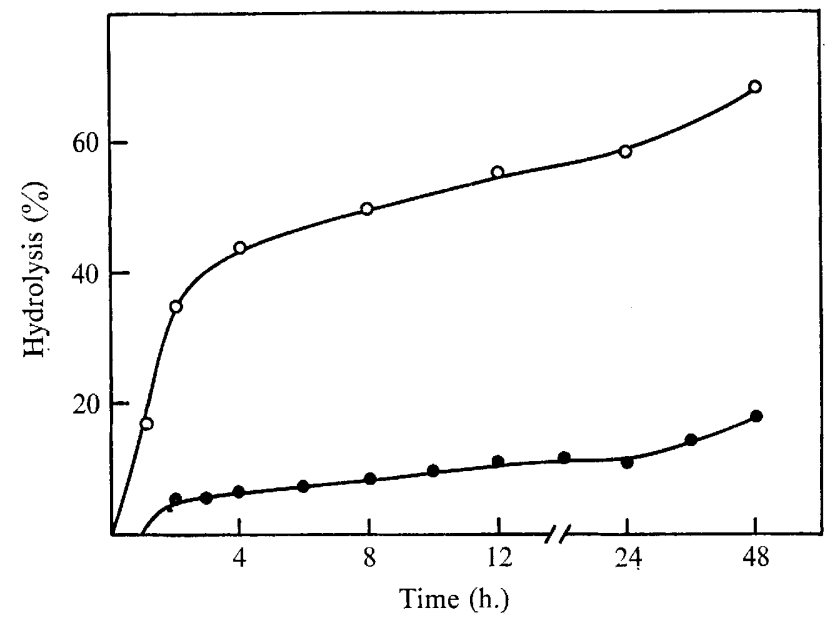

Fig. 2. Action of endopolygalacturonase on pectin (O) and polygalacturonic acid (O). The substrate concentration was $0.5 \%$ in $0.1 \mathrm{M}-\mathrm{Na}$ acetate buffer, $\mathrm{pH} 5.4$; enzyme concentration was 5.76 units for $80 \mathrm{ml}$. reaction mixture; at $30^{\circ}$. The reaction mixture was covered with a layer of toluene to avoid contamination.

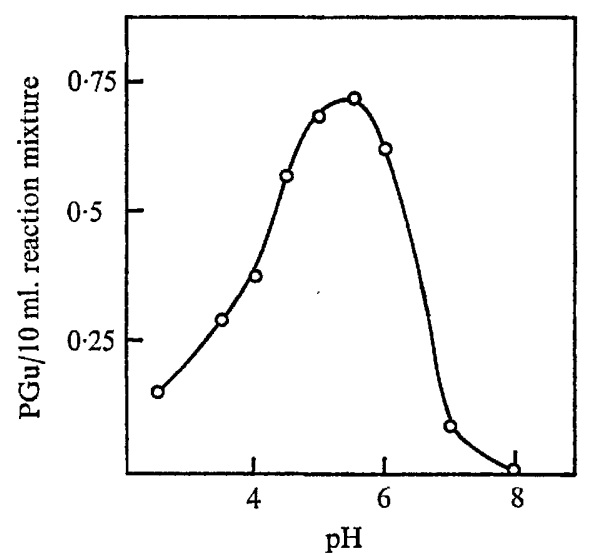

Fig. 3

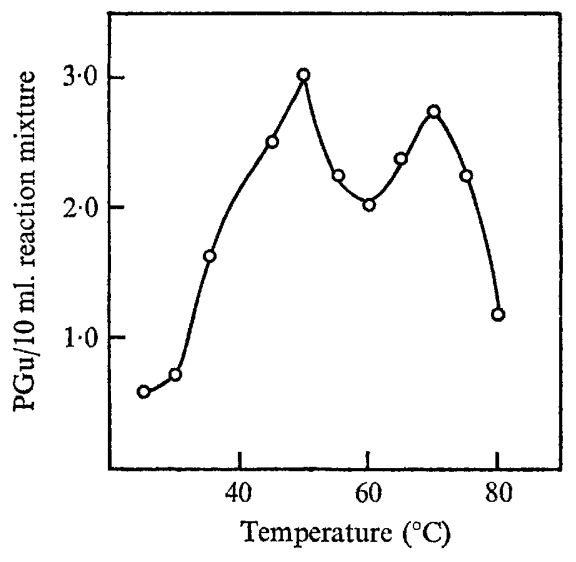

Fig. 4

Fig. 3. Effect of pH on endopolygalacturonase activity. The reaction mixture $\left(30^{\circ}\right)$ contained $\mathrm{r} \cdot 0 \%$ polygalacturonic acid, $\mathrm{I} 0 \mathrm{ml} ; \mathrm{I} \cdot 0 \mathrm{M}$ buffer of specified $\mathrm{pH}, 2 \cdot 0 \mathrm{ml}$; enzyme, $\mathrm{I} \cdot 44$ units; water to $20 \mathrm{ml}$.

Fig. 4. Effect of temperature on endopolygalacturonase activity. The reaction mixture contained polygalacturonic acid, $\mathrm{I} \cdot 0 \%$, Io ml.; acetate buffer, $\mathrm{I} \cdot 0 \mathrm{M}, \mathrm{pH} 5.4,2 \cdot 0 \mathrm{ml}$.; enzyme, I.44 units; and water to make up the volume to $20 \mathrm{ml}$. 
isozyme. However, attempts to separate these two activities on a DEAE-cellulose column were not successful.

Effect of various metal ions and inhibitors on enzyme activity. Mill (1966) reported the activation of exopolygalacturonase of Aspergillus niger by $\mathrm{Hg}^{2+}$ ions. Hence the effect of various metal ions at a final concentration of $\mathrm{I} \times \mathrm{IO}^{-3} \mathrm{M}$ on PG activity was tested. The purified enzyme did not require added metal ions for its activity. Except for $\mathrm{Fe}^{2+}$ and $\mathrm{Fe}^{3+}$ all metal ions tested inhibited $\mathrm{PG}$ activity: $\mathrm{Hg}^{2+}, \mathrm{Co}^{2+}$ and $\mathrm{Cu}^{2+}$ by $60 \%$ and $\mathrm{Ca}^{2+}, \mathrm{Mg}^{2+}, \mathrm{Mn}^{2+}$ and $\mathrm{Zn}^{2+}$ by $24 \%, 18 \%, 13 \%$ and $12.5 \%$ respectively. Neither $-\mathrm{SH}$ group binding agents like iodoacetate $\left(\mathrm{I} \times \mathrm{IO}^{-3} \mathrm{M}\right), p$-chloromercuribenzoate $\left(\mathrm{I} \times \mathrm{IO}^{-5} \mathrm{M}\right)$ and $N$-ethylmaleimide $\left(\mathrm{I} \times \mathrm{IO}^{-4} \mathrm{M}\right)$ nor sodium fluoride $\left(\mathrm{I} \times \mathrm{IO}^{-3} \mathrm{M}\right)$ and sodium azide $\left(\mathrm{I} \times \mathrm{IO}^{-4} \mathrm{M}\right)$ had any effect.

Effect of fungicides on enzyme action. These fungicides were tested at a final concentration of $0.1 \%$. Blitox-50 ( $50 \% \mathrm{Cu}$ as oxychloride) inhibited the enzyme by about $85 \%$ whereas maneb and zineb inhibited activity by about $7 \%$ and $21 \%$ respectively.

\section{DISCUSSION}

The secretion of endopolygalacturonase (EC 3.2.I. I5 polygalacturonide glycanohydrolase), i.e. the enzyme which attacks polygalacturonic acid, was demonstrated. The chromatographic study of the products of the action of the enzyme on polygalacturonic acid showed that this enzyme cleaved the chain at random. The enzyme had only feeble action on pectin, which showed that it was a polygalacturonase rather than a polymethylgalacturonase.

The method of purification described resulted in an approximately 65-fold purification of the endo-PG from the culture fluid of Ganoderma lucidum.

The Ganoderma PG had a very low specific activity (I $2 \cdot 9 \mathrm{PGu} / \mathrm{mg}$. protein) when compared with other PGs of yeast and fungal origin, e.g. $179 \mathrm{PGu} / \mathrm{mg}$. protein for the endo-PG of Saccharomyces fragilis (Phaff \& Demain, 1956) and I26I, 502 and $409 \mathrm{PGu} / \mathrm{mg}$. protein (converted from 7882, 3140 and $2560 \mathrm{PGu} / \mathrm{mg}$. of total nitrogen respectively) for three endo-PGs from Coniothyrium diploidella (Endo, 1964). However, the specific activity of Ganoderma PG closely resembled that of tomato and avocado PGs (Patel \& Phaff, 1960; Reymond \& Phaff, 1965).

Like the endo-PGs of Saccharomyces fragilis (Phaff \& Demain, 1956), Aspergillus saitoi (Yamasaki, Yasu \& Arima, 1966) and Coniothyrium diploidella (Endo, 1964) Ganoderma PG hydrolysed polygalacturonic acid to an extent of about $69 \%$; the reaction was fast and linear until $25 \%$ of the polygalacturonic acid was hydrolysed.

The optimum pH $(5 \cdot 0$ to 5.5$)$ for the Ganoderma PG was slightly higher than the values reported for other fungal and yeast PGs, which range from 3.3 to 4.8 (e.g. Demain \& Phaff, 1954; Luh \& Phaff, 1954; Mill \& Tuttobello, I961; Endo, 1964).

With optima at $50^{\circ}$ and $70^{\circ}$, the Ganoderma PG had remarkable thermal stability: polygalacturonases from most sources are rapidly inactivated at temperatures of $60^{\circ}$ and above, although a fraction of tomato enzyme has been found to resist $100^{\circ}$ for $5 \mathrm{~min}$. (McColloch \& Kertesz, 1948).

The authors thank Dr T. Ramakrishnan and Dr K. P. Gopinathan for their valuable suggestions, and Tata Fison Limited, India (Bangalore), for the gift samples of fungicides. 


\section{REFERENCES}

Bateman, D. F. \& Millar, R. L. (1966). Pectic enzymes in tissue degradation. Annual Review of Phytopathology 4, II9-I46.

BIlimoria, M. H. (1961). Microbial decomposition of pectic substances. Journal of the Indian Institute of Science 43, 16-25.

Bilimoria, M. H. (1962). Microbial Decomposition of Pectic Substances. Ph.D. thesis, Indian Institute of Science, Bangalore.

Brown, W. (1955). On the physiology of parasitism in plants. Annals of Applied Biology 43, 325-341.

Brown, W. (1965). Toxins and cell-wall dissolving enzymes in relation to plant disease. Annual Review of Phytopathology 3, I-I8.

Demain, A. L. \& Phaff, H. J. (1954). Hydrolysis of oligogalacturonides and pectic acid by yeast polygalacturonase. Journal of Biological Chemistry 210, 381-393.

Edstrom, E. D. \& Phaff, H. J. (1964). Purification and certain properties of pectin trans-eliminase from Aspergillus fonsecaeus. Journal of Biological Chemistry 239, 2403-2408.

ENDo, A. (1964). Studies on the pectolytic enzyme of mould. Agricultural and Biological Chemistry 28, $535-542,543-550,55 \mathrm{I}-558$.

Hathway, D. E. \& Seakins, J. W. T. (1958). The influence of tannins on the degradation of pectin by pectinase enzymes. Biochemical Journal 7o, I 58-163.

JANSEN, E. F. \& MACDONNELL, L. R. (1945). Influence of methoxyl content of pectic substances on the action of polygalacturonase. Archives of Biochemistry 8, 97-112.

LuH, B. S. \& PhafF, H. J. (1954). Properties of yeast polygalacturonase. Archives of Biochemistry and Biophysics 48, 23-37.

McColloch, R. J. \& KeRTeSZ, Z. I. (1948). An unusually heat-resistant pectolytic factor from tomatoes. Archives of Biochemistry 17, 197-199.

MiLl, P. J. (1966). The pectic enzymes of Aspergillus niger. Biochemical Journal 99, 557-56I.

Mill, P. J. \& Tuttobello, R. (I96I). The pectic enzymes of Aspergillus niger. Biochemical Journal 79, 57-64.

Naidu, G. V. B., Kumar, S. N. \& Sannamarappa, M. (I966). Ganoderma lucidum (Leys) Karst on arecanut palm. Lalbaugh Journal (India), pp. I4-20.

Phaff, H. J. \& Demain, A. L. (1956). The unienzymatic nature of yeast polygalacturonase. Journal of Biological Chemistry 218, 875-884.

PATel, D. S. \& PhafF, H. J. (1960). Studies on the purification of tomato polygalocturonase. Food Research 25, 37-46.

ReYMond, D. \& PhAFF, H. J. (1965). Purification and certain properties of avocado polygalacturonase. Journal of Food Science 30, 226-273.

Sadasivan, T. S. \& Subramanian, D. (1963). Pectic enzymes and plant disease. Journal of the Indian Botanical Society 42 A, I99-2I2.

Venkatarayan, S. V. (1936). The biology of Ganoderma lucidum on arecanut and coconut palms. Phytopathology 26, I53-175.

WARBurg, O. \& Christian, W. (I94I). Isolierung und Kristallisation des Gärungferments Enolase. Biochemische Zeitschrift 3ro, 384-42 I.

WATT, G. (I90I). A plague of betel-nut palms and the destruction of the tissues by what appears to be a form of tylosis. Agricultural Ledger 8, I29-179.

Wood, R. K. S. (1959). In Plant Pathology Problems and Progress 1908-1958, pp. 100-109. Edited by C. S. Holton, G. W. Fisher, R. W. Fulton, H. Hart, S. E. A. McCallan. Madison: University of Wisconsin Press.

Wood, R. K. S. (1960). Pectic and cellulolytic enzymes in plant disease. Annual Review of Plant Physiology II, 299-322.

YAMASAKI, M., YASU, T. \& ARIMA, K. (I966). Studies on pectic enzymes of micro-organisms. Agricultural and Biological Chemistry (Japan) 30, I I I9-I I 28. 